UDC 373

\title{
Experimental pedagogical activity when teaching computer science to younger students
}

\author{
Viktor S. Kornilov, Svetlana V. Morozova \\ Moscow City University \\ 29 Sheremetyevskaya St, Moscow, 127521, Russian Federation
}

\begin{abstract}
Problem and goal. One of the important components of the educational and methodical work of a teacher who teaches computer science to younger students is the quality control of the acquired system of knowledge of schoolchildren, which involves experimental pedagogical activity. Such experimental pedagogical activities include pedagogical experiments, the results of which are processed and analyzed using mathematical methods. Pedagogical measurements allow to justify the effectiveness of the implemented teaching methodology.

Methodology. Pedagogical measurements are carried out in pedagogical research aimed at improving the content, methods, forms and means of teaching computer science to younger students using didactic games. The pedagogical experiment itself includes ascertaining, searching, forming and controlling stages. The analysis of the results of pedagogical measurements aimed at identifying the quality of the obtained knowledge in computer science of younger students can be effectively carried out using mathematical and statistical methods.

Results. The conducted pedagogical measurements allow to draw a conclusion about how much younger students have subject knowledge in computer science, which is taught using didactic games; to identify the level of their worldview, logical thinking.

Conclusion. Experimental pedagogical activity of the teacher in the process of teaching computer science to younger students allows to identify the effectiveness of such training, the level of subject knowledge of students. Analysis of the results of pedagogical measurements allows, if necessary, to correct the methodology and content of training in computer science.
\end{abstract}

Key words: teaching computer science to younger students, information technologies, didactic games, pedagogical measurements

Problem statement. In modern conditions, computer science plays an important role in the development of world science and scientific and technical progress, the formation of knowledge and culture of modern society. Today, computer science as an academic discipline has become a fundamental discipline. It is included in the content of both school education and university education of students in various fields of training. In the development of informatics as an academic discipline has contributed to studies of such authors as G.S. Batrshina, S.A. Beshenkov, T.A. Baronenko, L.L. Bosova, N.N. Bulgakov, A.V. Goryachev, A.A. Gra- 
chev, S.G. Grigoriev, V.V. Grinshkun, L.M. Dergacheva, O.Ju. Zaslavskaya, T.B. Zakharova, G.A. Zvenigorodsky, R.R. Kamalov, S.D. Karakozov, A.A. Kuznetsov, M.P. Lapchik, I.V. Levchenko, N.In. Makarova, Yu.A. Pervin, A.E. Rakitin, I.G. Semakin, A.R. Esayan, A.J. Friedland and other authors (see, e.g., [1; 4-7]).

In science lessons to grade school students master the theoretical concepts underlying the course, the initial ideas about the information picture of the world, learn to use computer technology as a means of working with information in academic and daily life, develop the initial ability to select necessary information, to understand and apply this information in solving academic tasks is the process of nurturing interest in information activities, the ethical standards of information selection and the education of careful attitude to electronic devices.

In the learning process students, mastering the content of the course of informatics and reinforcing practice, solve various assignments and exercises, for example, call color, shape, size of objects, continue a predetermined number, thereby learning to build an algorithm to search a sequence; giving the name of the objects, divide them into groups, learn to combine and classify items into groups by common characteristics, learn about the concept of composite parts; establish spatial relationships "greater than", "less", "same"; compare sets, solve problems using arithmetic, remember mathematical terms; encode information using the alphabet in forward and reverse order; build and parse statements, learn the basics of logic; make algorithms cyclic, branching, linear, learn the basics of programming.

In the process of completing educational tasks, students not only master the theoretical material on computer science, but also can practically work out the skills and abilities of working at the computer. The system of tasks for primary school in computer science, implemented on a computer, will improve the quality of education of students and develop their creative abilities, and this contributes to the formation of their deep knowledge of computer science.

In the process of teaching computer science, students develop their worldview, logical and informational thinking, and knowledge of such fundamental concepts as information, algorithmization, syntax, modeling, formalization, and other concepts of computer science. The effectiveness of teaching school informatics is achieved through the formation of the content of training, the full implementation of the goals, principles, forms, tools and methods of training. One of the most effective methods of teaching students computer science is the game (game technologies, didactic games, business games, computer games) (see, for example, [2; $3 ; 6 ; 7 ; 9 ; 13-15])$.

The use of didactic games in the process of teaching students computer science using computerization tools allows them to form a system of knowledge in the discipline, to develop their creative abilities. A traditional lesson differs from a lesson using didactic games in that problem situations are formed independently. At this lesson, students are not in any limits or under pressure of restrictions, they have the right to make mistakes. At the same time, they can show independence, actively and creatively approach the tasks.

Such authors as S.A. Bizyaeva, A.K. Bondarenko, N.N. Bulgakova, N.A. Vladimirova, L.M. Dergacheva, R.R. Kamalov, A.L. Katkova, T.G. Ryseva, N.I. Nikulina, S.V. Ilchenko, D.G. Zhemchuzhnikov, O.N. Polschikova and others made 
a significant contribution to the development of methods of teaching informatics to schoolchildren using the game approach (see, for example, $[2 ; 4 ; 6 ; 7 ; 9 ; 12]$ ).

Participation in didactic games in computer science lessons gives students the opportunity to improve their creative thinking, to understand the importance of the material being studied and the meaning of the concepts being studied in computer science more deeply.

The use of didactic games in teaching computer science to primary school students contributes to the comprehensive development of their personality, active mental growth, and deep and meaningful learning. Therefore, the development of individual abilities of students should be taken into account when developing such training content. In addition, didactic games in computer science lessons can be selected individually in accordance with the level of subject knowledge of younger students. With this approach, each student will be able to acquire the necessary knowledge and skills, but at a different level.

Methods of research. One of the important components of the educational and methodological work of a teacher who teaches computer science to younger students is the quality control of the acquired system of knowledge of schoolchildren, which is carried out as a result of experimental pedagogical activity. Such experimental pedagogical activity usually involves conducting pedagogical experiments, the results of which are processed and analyzed using various mathematical methods. For example, after studying the topic "Types of information, human and computer", the quality of learning the educational material and the content of such fundamental concepts as information, sound information, taste information, tactile (tactile) information, olfactory information, visual (visual) information, computer, keyboard, monitor, mouse, system unit can be determined.

Experimental pedagogical activity is carried out at different stages of pedagogical research aimed at identifying and justifying pedagogical influences, such as the content, methods, forms and means of teaching. Pedagogical experiment, as a rule, consists of ascertaining, searching, forming and controlling stages. When conducting such experimental pedagogical activities, a variety of approaches can be used, including the use of mathematical methods for processing the results of pedagogical measurements. Statistical methods, among other things, allow making an informed decision about the results of the pedagogical experiment (see, for example, $[8 ; 10])$.

One of these methods is the method of calculating the linear Pearson correlation coefficient, which can be used to calculate the correlation between increasing the level of fundamental knowledge in the field of computer science and the ability to perform training tasks independently; the degree of influence of computer science training on the formation of creative abilities and worldview in younger students.

The Pearson coefficient $r_{x y}$ is determined by the formula:

$$
r_{x y}=\frac{n \sum_{i=1}^{n} x_{i} y_{i}-\sum_{i=1}^{n} x_{i} \sum_{i=1}^{n} y_{i}}{\sqrt{\left(n \sum_{i=1}^{n} x_{i}^{2}-\left(\sum_{i=1}^{n} x_{i}\right)^{2}\right)\left(n \sum_{i=1}^{n} y_{i}^{2}-\left(\sum_{i=1}^{n} y_{i}\right)^{2}\right)}},
$$


where $n$ means the number of observations being compared; $x_{i}$ and $y_{i}$ mean the quantitative features being compared.

Among the mathematical methods that can be used to assess the quality of primary school students' subject knowledge in computer science, the following methods can be used.

1. The method of V.P. Bespalko, which can be used to identify the level of learning of educational material in school computer science, using the value of the coefficient $k=\frac{n}{N}$, which $n$ determines the number of points scored by younger students, $N$ determines the maximum number of points for younger students.

2. The method of A.V. Usova, which allows to reveal the completeness of assimilation by younger students of the content of concepts used in the process of teaching computer science, by the value of the coefficient $K$, which is determined by the formula: $K=\frac{1}{p \cdot n} \sum_{i=1}^{n} p_{i}$ where $p_{i}$ denotes the number of essential features of concepts learned $i$-th student, $p$ means the total number of attributes of the concept, $n$ means the number of students in the class.

The Microsoft Office Excel software allows to calculate the value of the above coefficients, as well as to build various visual diagrams.

Results and discussion. The obtained results of pedagogical experiments allow to draw a conclusion about how successfully younger students have fundamental knowledge in the field of computer science, which is taught using didactic games.

Conclusion. In the process of teaching younger students computer science using didactic games, experimental pedagogical activity of the teacher allows to identify how successfully such training is conducted. The results of pedagogical measurements clearly demonstrate the level of subject knowledge of younger students in computer science and help, if necessary, to adjust the methodology and content of training in computer science using didactic games.

\section{References}

[1] Batrshina GS. Formirovanie logicheskih umenij u mladshih shkol'nikov na osnove realizacii mezhpredmetnyh svyazej informatiki i matematiki [Formation of logical skills in younger students based on the implementation of intersubject connections of computer science and mathematics] (abstract of the dissertation of the Candidate of Pedagogical Sciences). Moscow; 2014.

[2] Bizyaeva SA. Igrovye formy interaktivnogo obucheniya kak sredstvo razvitiya poznavatel'nogo interesa studentov [Game forms of interactive learning as a means of developing students' cognitive interest $]$ (abstract of the dissertation of the Candidate of Pedagogical Sciences). Yaroslavl'; 2007.

[3] Bondarenko AK. Vospitanie detej v igre [Education of children in the game]. Moscow: Prosveshchenie Publ.; 2008.

[4] Bulgakova NN. Aktivnaya deyatel'nostno-igrovaya uchebno-informacionnaya sreda propedevticheskogo kursa informatiki v nachal'noj shkole [Active activity-game educa- 
tional and information environment of the propaedeutic course of informatics in primary school] (dissertation of the Candidate of Pedagogical Sciences). Voronezh; 2002.

[5] Goryachev AV. Metodika obucheniya informatike v nachal'noj shkole, realizuyushchaya ob"ektno-informacionnyj podhod [Method of teaching informatics in primary school, implementing the object-information approach] (dissertation of the Candidate of Pedagogical Sciences). Saint Petersburg; 2004.

[6] Dergacheva LM. Razvitie poznavatel'noj aktivnosti shkol'nikov na osnove organizacii uchebno-igrovoj deyatel'nosti pri obuchenii informatike [Development of cognitive activity of school children on the basis of organization of educational and game activity when teaching informatics] (dissertation of the Candidate of Pedagogical Sciences). Moscow; 2006.

[7] Kamalov RR. Komp'yuternye igry kak element shkol'nogo kursa informatiki [Computer games as an element of the school course of informatics]. Informatika i obrazovanie [Informatics and education]. 2004;(5):76-77.

[8] Kartashova LI, Kornilov VS, Levchenko IV. Primenenie matematicheskih metodov v pedagogicheskih izmereniyah [Application of mathematical methods in pedagogical measurements]: educational and methodological guide. Moscow: MGPU Publ.; 2010.

[9] Katkova AL. Komp'yuternye igry kak sredstvo stimulirovaniya poznavatel'nogo interesa budushchih uchitelej $k$ prakticheskim zanyatiyam informatikoj [Computer games as a means of stimulating the cognitive interest of future teachers to practice computer science] (dissertation of the Candidate of Pedagogical Sciences). Ekaterenburg; 2007.

[10] Kornilov VS. Eksperimental'naya proverka effektivnosti obucheniya studentov obratnym zadacham dlya differencial'nyh uravnenij [Experimental verification of the effectiveness of teaching students inverse problems for differential equations]. Vestnik Moskovskogo gorodskogo pedagogicheskogo universiteta. Seriya: Informatika i informatizacija obrazovanija [Bulletin of the Moscow City Pedagogical University. Series: Informatics and Informatization of Education]. 2014;4(30):66-78.

[11] Kornilov VS, Morozova SV. Metodicheskie podhody k strukturirovaniyu soderzhaniya obucheniya informatike $\mathrm{v}$ nachal'noj shkole s ispol'zovaniem didakticheskih igr [Methodological approaches to structuring the content of computer science education in primary schools using didactic games]. Vestnik Moskovskogo gorodskogo pedagogicheskogo universiteta. Seriya: Informatika i informatizacija obrazovanija [Bulletin of the Moscow City Pedagogical University. Series: Informatics and Informatization of Education]. 2019;3(49):24-32.

[12] Korotkova NA. Sovremennye issledovaniya detskoj igry [Modern research of children's play]. Available from: http://www.voppsy.ru/issues/1985/852/852163.htm (accessed: 20.09.2019).

[13] Morozova SV. Metodicheskie podhody k obucheniyu informatike s ispol'zovaniem igrovogo metoda [Methodological approaches to teaching computer science using the game method]. Vestnik Moskovskogo gorodskogo pedagogicheskogo universiteta. Seriya: Informatika i informatizacija obrazovanija [Bulletin of the Moscow City Pedagogical University. Series: Informatics and Informatization of Education]. 2017;4(42):100-105.

[14] Morozova SV. Computer technology in the didactic games in science lessons in junior high. RUDN Journal of Informatization in Education. 2019;16(1):73-80.

[15] Ryseva TG. Sistema didakticheskih igr kak sredstvo razvitiya poznavatel'noj samostoyatel'nosti shkol'nikov [System of didactic games as a means of developing students' cognitive independence] (dissertation of the Candidate of Pedagogical Sciences. Izhevsk; 2003.

\section{Article history:}

Received: 15 October 2019

Accepted: 15 November 2019 


\title{
For citation:
}

Kornilov VS, Morozova SV. Experimental pedagogical activity when teaching computer science to younger students. RUDN Journal of Informatization in Education. 2020;17(1): 18-25. http://dx.doi.org/10.22363/2312-8631-2020-17-1-18-25

\section{Bio notes:}

Viktor S. Kornilov, doctor of pedagogical sciences, candidate of physical and mathematical sciences, full professor, deputy head of the department of informatization of education of the Moscow City University. E-mail: vs_kornilov@mail.ru

Svetlana V. Morozova, post-graduate student of the department of informatization of education of the Moscow City University. E-mail: suhova-svetlanka@mail.ru

Научная статья

\section{Экспериментальная педагогическая деятельность при обучении информатике младших школьников}

\author{
В.С. Корнилов, С.В. Морозова \\ Московский городской педагогический университет \\ Российская Федераџия, 127521, Москва, ул. Шереметьевская, 29
}

\begin{abstract}
Аннотация. Проблема и цель. Одной из важных составляющих учебно-методической работы педагога, осуществляющего обучение информатике младших школьников, является контроль качества приобретаемой системы знаний школьников, который предполагает экспериментальную педагогическую деятельность. В такую экспериментальную педагогическую деятельность входят педагогические эксперименты, результаты которых обрабатываются и анализируются с помощью математических методов. Педагогические измерения позволяют обосновать эффективность реализуемой методики обучения.

Методология. Педагогические измерения проводятся в педагогических исследованиях, которые направлены на улучшение содержания, методов, форм и средств обучения младших школьников информатике с использованием дидактических игр. Сам педагогический эксперимент включает констатирующий, поисковый, формирующий и контролирующий этапы. Анализ результатов педагогических измерений, направленных на выявление качества получаемых знаний по информатике младших школьников, эффективно может быть осуществлен с использованием математических и статистических методов.
\end{abstract}

Результаты. Проведенные педагогические измерения позволяют сделать вывод о том, насколько младшие школьники обладают предметными знаниями по информатике, обучение которой осуществляется с использованием дидактических игр, выявить уровень их мировоззрения, логического мышления.

Заключение. Экспериментальная педагогическая деятельность педагога в процессе преподавания информатики младшим школьникам позволяет выявить эффективность такого обучения, уровень предметных знаний школьников. Анализ результатов педагогических измерений дает возможность при необходимости скорректировать методику и содержание обучения по информатике.

Ключевые слова: обучение младших школьников информатике, информационные технологии, дидактические игры, педагогические измерения 


\section{Список литературы}

[1] Батршина Г.С. Формирование логических умений у младших школьников на основе реализации межпредметных связей информатики и математики: автореф. дис. ... канд. пед. наук. М., 2014. 187 с.

[2] Бизяева C.A. Игровые формы интерактивного обучения как средство развития познавательного интереса студентов: автореф. дис. ... канд. пед. наук. Ярославль, 2007. $212 \mathrm{c}$.

[3] Бондаренко А.К. Воспитание детей в игре. М.: Просвещение, 2008. 137 с.

[4] Булгакова Н.Н. Активная деятельностно-игровая учебно-информационная среда пропедевтического курса информатики в начальной школе: дис. ... канд. пед. наук. Воронеж, 2002. 273 с.

[5] Горячев A.B. Методика обучения информатике в начальной школе, реализующая объектно-информационный подход: дис. ... канд. пед. наук. СПб., 2004. 183 с.

[6] Дергачева Л.М. Развитие познавательной активности школьников на основе организации учебно-игровой деятельности при обучении информатике: дис. ... канд. пед. наук. М., 2006. 173 с.

[7] Камалов P.P. Компьютерные игры как элемент школьного курса информатики // Информатика и образование. 2004. № 5. С. 76-77.

[8] Карташова Л.И., Корнилов В.С., Левченко И.В. Применение математических методов в педагогических измерениях: учебно-методическое пособие. М.: МГПУ, $2010.50 \mathrm{c}$.

[9] Каткова А.Л. Компьютерные игры как средство стимулирования познавательного интереса будущих учителей к практическим занятиям информатикой: дис. ... канд. пед. наук. Екатеринбург, 2007. 145 с.

[10] Корнилов В.С. Экспериментальная проверка эффективности обучения студентов обратным задачам для дифференциальных уравнений // Вестник Московского городского педагогического университета. Серия: Информатика и информатизация образования. 2014. № 4. С. 66-78.

[11] Корнилов В.С., Морозова С.В. Методические подходы к структурированию содержания обучения информатике в начальной школе с использованием дидактических игр // Вестник Московского городского педагогического университета. Серия: Информатика и информатизация образования. 2019. № 3. С. 24-32.

[12] Короткова H.A. Современные исследования детской игры. URL: http://www.voppsy.ru/ issues/1985/852/852163.htm (дата обращения: 20.09.2019).

[13] Морозова C.B. Методические подходы к обучению информатике с использованием игрового метода // Вестник Московского городского педагогического университета. Серия: Информатика и информатизация образования. 2017. № 4 (42). C. $100-105$.

[14] Морозова С.В. Информационные технологии в дидактических играх на уроках информатики в младших классах // Вестник Российского университета дружбы народов. Серия: Информатизация образования. 2019. Т. 16. № 1. С. 73-80.

[15] Рысьева Т.Г. Система дидактических игр как средство развития познавательной самостоятельности школьников: дис. ... канд. пед. наук. Ижевск, 2003. 230 с.

\section{История статьи:}

Дата поступления в редакцию: 15 октября 2019

Дата принятия к печати: 20 ноября 2019

\section{Для цитирования:}

Kornilov V.S., Morozova S.V. Experimental pedagogical activity when teaching computer science to younger students (Экспериментальная педагогическая деятельность при обучении информатике младших школьников) // Вестник Российского университета 
дружбы народов. Серия: Информатизация образования. 2020. Т. 17. № 1. С. 18-25. http://dx.doi.org/10.22363/2312-8631-2020-17-1-18-25

\section{Сведения об авторах:}

Корнилов Виктор Семенович, доктор педагогических наук, кандидат физико-математических наук, профессор, профессор кафедры информатизации образования Московского городского педагогического университета. E-mail: vs_kornilov@mail.ru

Морозова Светлана Валерьевна, аспирант кафедры информатизации образования Московского городского педагогического университета. E-mail: suhova-svetlanka@mail.ru 